\title{
The Relationship Between Employee Motivation And Employee Performance in BPR TASPEN
}

\author{
Salsabila Maharani Surya Putri ${ }^{1}$, Nur Arief Rahmatsyah Putranto ${ }^{2}$ \\ Management and Business School, Bandung Institute of Technology \\ ${ }^{1}$ Salsabila_maharani@sbm-itb.ac.id, ${ }^{2}$ nur.arief@sbm-itb.ac.id
}

\begin{abstract}
BPR DP TASPEN, one of the BPR in Indonesia, faces the problem of unmotivated employees. After employees were interviewed, the company is known to never assess the motivation of their employees to work as an appropriate basis to trigger them to do maximum work. ERG Alderfer (1969) Theory was used in this study to assess employee motivation. Questionnaire is used to collect the data of 63 employees which then analyzed with multiple linear regression. The results show that the relatedness is the only one which significantly related to employee performance. Therefore, it can be concluded that if employers focus on the relatedness needs or use the need as a base to collaborate with the other needs, the motivation of employees to perform best may increase. Thus BPR DP TASPEN is suggested to make a gathering, open discussion feedback, or inviting a well-known trainer or work motivator which proposed by the employees itself, to maintain the satisfaction of the needs.
\end{abstract}

Keywords: Employee Performance, ERG Alderfer Theory, Rural Bank, Work Motivation

This is an open access article under the CC-BY-NC license.

\section{INTRODUCTION}

Retirees are still be a lucrative market for banks to boost lending (Kartika, 2019). It is still considered promising, given the number of workers preparing for retirement continues to increase each year (Rafie, 2018). The definition of retiree itself according to Kasmir (2012) is the individual who accept the right to earn income after working for many years, and has reached retirement age or there are other reasons as set out in the agreement. A retiree will receive pension funds program which enable accumulated funds that needed to maintain sustainability of the income of participants for their retirement period. Pension funds gives assurance and build positive motivation to employees and lead higher productivity in their job (Financial Service Authority, 2017).

Indonesia has State Owned Enterprise whose engaged in the insurance of old age savings and pension funds for civil servant and state officials known as PT TASPEN (TASPEN, 2018). PT TASPEN control pension benefits to civil servants based on the provision of Law No 11/1969. Meanwhile, in compliance with Law 11/1966, members of the TNI or Polri received ASABRI managed their pension benefits (Chandra \& Pramisti, 2017). 
There is additional pension benefits that are not mandatory and retrieved from Law No. $11 / 1992$ explain that it is a legal basis. Companies with many employees generally manage their own pension funds. PT TASPEN as one of Indonesian State Owned Enterprise could use the right to manage their own employee pension fund. PT TASPEN then build TASPEN Pension Fund or DP TASPEN.

TASPEN Pension Fund firstly named 'Yayasan Sejahtera.' In 1987 the goals of the foundation changed to regulate old-age insurance and concern to the welfare of PT TASPEN directors, employees, and their families. Law Number 11 of 1992 issued, the foundation form was changed to the pension fund format, then it officially resulted in the TASPEN Pension Fund or DP TASPEN, (Dana Pensiun Karyawan Taspen, 2020). DP TASPEN then launched a rural bank as it subsidiary company and to reach the objective of the foundation which is to improve and prosper PT TASPEN employees'.

According to Law Number 10 of 1998 Article 5 rural bank or BPR is a bank that is the same as a commercial bank but does not offer payment services except in business activities which involve only collecting funds from the public in the form of time deposits, loans, credit, and putting funds in the form of Bank Indonesia Certificates. Rural banks are not allowed to accept deposits in the form of demand deposits, to conduct foreign currency transactions, to engage in equity participation, and to conduct insurance business (Iskandar S, 2013). Rural banks or BPR typically have monopoly control because people in their regions where there are few commercial banks face some trouble accessing funds (Hidayat et al., 2012).

Through the approval of the Minister of Law and Human Rights of the Republic of Indonesia, the name of rural bank owned by PT TASPEN is PT BPR DP TASPEN. The company officially established in January 1990 with the headquarters located in Bekasi, West Java. BPR DP TASPEN has seven branches spread over Greater Jakarta and West Java. The company is an extension of the DP TASPEN, which is indirectly also an official channel of PT TASPEN. BPR DP TASPEN becomes one of four rural banks in Indonesia that become PT TASPEN pay partners.

Almost all of the businesses out there in the world use human resource department because in reality, the department of human resources has the ability to handle an organisation's most significant and valuable resources. Without a properly functioning human resource department, a firm would fail to achieve a high level of efficiency and management of the workforce (Chhugani, 2018). Human resource management (HRM) is primarily focused on employee performance, as it involves employee behavior related to the achievement of organizational goals or targets (Beltrán et al., 2018). Human resource outcomes, such as employee skills and motivation, facilitate the impact of human resource activities on productivity, quality, service, innovation, and other operational outcomes, which further affect financial outcomes representing the accomplishment of targets or the outcomes of the company (Jiang et al., 2012). The company sets targets for specific aspects of employee performance, such as financial returns or the quality of services offered to assess and evaluate their performance (Staroňová, 2017).

Based on the data and from the interview, the symptom is employees not achieve their target which reflected in the company performance. The performance itself could be assessed by using financial ratio analysis (FRA) analysis. Financial ratios assess performance with ratios based on yearly statements. The use of financial ratios means that banks intend to minimize expenses, optimize income or increase profits, and are well-established benefit proxies for income-making (Alexakis, Izzeldin, Johnes, \& Pappas, 2019). It will be beneficial in making important decisions for investors or credit rating professionals (ho \& Zhu, 2004).

According to the data from the General Meeting of BPR DP TASPEN Shareholders, the Capital Adequacy Ratio (CAR), Return on Asset (ROA), Cash Ratio (CR), Loan to Deposit Ratio (LDR) realization for $2017-2020$ are not achieve the budget plan target. 
The company's performance then compared with the bank industry condition to validate whether the problem occur either normal to occur or not. Statistics Indonesia (2019) approve the fact that the financial services and insurance sector in the 2017 period contributed $4.2 \%$ to Gross Domestics Product (GDP). GDP become an indicator to know the economic conditions in a country. Then in 2018 the financial services and insurance contributed 4.15\% to GDP, and in 2019 rose to $4.24 \%$. It can be concluded that BPR, as one of the business in the financial service and insurance sector did not grow in line with the growth of the contribution of Gross Domestic Product to the Indonesian economy.

The data of company's performance is supported by Mr. Iqbal's statement that there is a decline in employee individual performance of 2018-2019 which is $-2 \%$, which becomes a sign that employees did not give their best effort or maximum performance than previous year to reach company plan or target. Záme (2014) explained that company's performance are realized through its employees' performance. The employee not only failed to achieve their target but also late going to work and left the workplace after attending the fingerprint scan. Those are the sign of not engaged employees. Webb et al (2015) explained that employee whose engaged with their employer is less likely to miss work or prevent exposing liability and danger to the employer, such as fault or failure to meet their target. Not engaged employees will expose the employer to fault or damage to their employer. This problem will not happen if employees are motivated to go to work because there is a positive relationship between a not engaged employee and employee motivation.

The interview with Mr. Suryo and Ms. Yulia, confirmed that there is a report of not motivated employees. Mr. Suryo, in the interview, also mentioned that the company only uses the bonus to motivate the company and think that all the employees are motivated with that. This is happening because the company never assess their employee motivation to work as the right base for triggers them to give maximum works because a study said that improper employee motivation program could damage employee performance. Employee motivation (program) related to employee performance. Thus assessing employee motivation is conducted to know what factor motivates them to work to solve the problem that occurred, which is the decline of employee performance.

\section{LITERATURE REVIEW}

\subsection{ERG Alderfer Motivational Needs Theory}

As a factor that triggers each employee can be different from each other, focus on how to prioritize various factors is the key to content theory's motivation (Rhee, 2019). This research will use Alderfer's ERG theory since it is one attempt to modify Maslow's hierarchy, which known to identify individual needs for the purpose of motivating behavior by reducing the number of need categories (Wiley, 1997). Alderfer found only three levels of needs are existence, relatedness, and growth, which have been developed through qualitative and quantitative empirical studies to understand how employees might improve job performance (Caulton, 2012). Clay Alderfer developed a theory of human need that differs from Maslow's in three major ways in 1969. There are three sets of core needs, existence needs(E), relatedness needs(R), and growth needs $(G)$. The difference between Alderfer's theory and Maslow's are first, the integration of psychological and security needs into existence needs. Secondly, the need for affiliation and external esteem are categorized as relatedness needs. Whereas internal esteem needs include in growth needs, along with self-actualization needs. Third, Alderfer's theory does not propose that needs are related to one another hierarchically and that more than one need can be activated simultaneously. Lastly, the ERG theory has a model called the frustration-regression component, which explains the frustration of higher-order needs can influence the desire to lower-order needs. 


\subsection{Employee Performance}

The performance of employees is a topic that has received widespread attention in literature and study because of its significance as each organization strives to achieve higher performance (Jerome, 2013). Employee performance involves employee behavior related to the achievement of organizational goals or targets (Beltrán-Martín \& Bou-Llusar, 2018). In order to utilize HR fully and augment organizational success, an effective employee performance management system is imperative for a business organization as it expected to be aligned with the organizational policies (Pradhan \& Jena, 2017). Jerome (2013) explained more that performance of employees refers to measurable attitudes and acts that describe how a job is done, plus the results desired for optimal work performance. According to Dugovicova (2019), employee performance includes production quality and quantity, appearance at work, friendly with supportive disposition, and production timeliness.

\subsection{Employee Motivation and Employee Performance}

In this increasingly globalized society, companies are continuously seeking to grow and motivate their employees to help achieve better performance through different applications and activities of Human Resource (Dugovicova, 2019). Motivation improves employee performance, productivity, and employee commitment (Nnenna E. Ukandu, 2011). Chiang \& Jang (2008) highlighted the urgency of motivation since employees recognize that if they work hard, their performance will improve significantly. When they are highly motivated, they will put more effort into the work and improve their efficiency and performance quality. Motivation found to become one of the determinant factors of employee performance aspects (Sato et al., 2017). Highly effective organizations proved to promote both high-quality performance and motivation to work (Deci et al., 2017). Taghipour \& Dejban (2013) revealed in their research that work motivation fully mediated job performance and stated that employees' motivation is one of the most effective managers' strategies to enhance effective employees' job performance

\section{RESEARCH METHODOLOGY}

In this research, the method used is quantitative, which explains the causal relationship between the independent variable and the dependent variable. Researcher uses two models, the first model will analyse the self-assessment result collected directly from the employees and the second will analyse the assessment result filled by the human resource of BPR TASPEN. The second model aimed to make sure the research is relevant with the most recent employee performance. The population in this study were all permanent employees with total of 63 employees. According to Sugiyono (2018) this method is calculated as sampling named saturation sampling. It used when the population is below 100 people. The questionnaire is made up of some sort of questions that reflect the process used to collect the data required for the study. The Likert Scale 1-5 used in both models to evaluate the questionnaire's point of each question. After the data is collected, Multiple Linear Regression is used to determine how much influence a dependent variable has on more than one independent variables.

\section{FINDING AND DISCUSSION}

\subsection{Validity and Reliability}

The correlation technique uses Pearson Correlation, calculated using SPSS version 23 computer program. The question items are declared valid if they have $r$ count $>r$ table (Ghozali, 2001). The Rtable of $n=63$ with significance level of $95 \%$ is 0.248 . The data clarified as valid because the Pearson 
Proceeding on Management, Education and Social Science (MESS),

$$
\text { Vol. } 1 \text { (1), 22-34 }
$$

The Relationship Between Employee Motivation And Employee Performance in BPR TASPEN Salsabila Maharani Surya Putri, Nur Arief Rahmatsyah Putranto

coefficient correlation is higher than the R-table. The reliability test of each variables as can be seen are passes the critical point used which is 0.6 thus the data known is reliable. The reliability test of each variables as can be seen in Figure 4.1 are passes the critical point used which is 0.6 thus the data known is reliable.

\begin{tabular}{|c|c|c|c|c|c|c|}
\hline Label & Variable & Sub-variable & Dimension & Question & Pearson Correlation & R-Table \\
\hline El & \multirow{23}{*}{$\begin{array}{l}\text { Employee } \\
\text { Motivation }\end{array}$} & \multirow{17}{*}{$\begin{array}{l}\text { Existence } \\
\text { Needs }\end{array}$} & \multirow{4}{*}{$\begin{array}{l}\text { Good pay to fulfil } \\
\text { psychological } \\
\text { needs }\end{array}$} & Compared to similar work in other places my pay is poor. & 0.852 & 0.248 \\
\hline E2 & & & & Compared to the rate for less demanding jobs, my pay is poor. & 0.882 & 0.248 \\
\hline E3 & & & & My pay is sufficient to provide for the necessities of life. & 0.726 & 0.248 \\
\hline E4 & & & & Considering the job that needs to be done, compensation is what it should be. & 0.783 & 0.248 \\
\hline E5 & & & \multirow{10}{*}{ Fringe Benefits } & Our fringe benefits do not cover many of the areas they should. & 0.633 & 0.248 \\
\hline E6 & & & & The fringe benefit program here gives nearly all the security I want. & 0.645 & 0.248 \\
\hline E7 & & & & Compared to other places, our fringe benefits are excellent. & 0.790 & 0.248 \\
\hline R1 & & & & My boss will play one person against another. & 0.543 & 0.248 \\
\hline R2 & & & & My boss has taken my wishes and wishes into consideration. & 0.751 & 0.248 \\
\hline R3 & & & & My boss discourages people from making suggestions. & 0.674 & 0.248 \\
\hline R4 & & & & It's easy to talk with my boss about my job. & 0.730 & 0.248 \\
\hline R5 & & & & My boss does not let me know when I could improve my performance. & 0.785 & 0.248 \\
\hline R6 & & & & My boss gives me credit when I could do good work. & 0.681 & 0.248 \\
\hline R7 & & & & My boss keeps me up to date with what's going on in the company. & 0.423 & 0.248 \\
\hline R8 & & & \multirow{3}{*}{ Respect from Peers } & My co-workers are uncooperative unless it's to their advantage. & 0.609 & 0.248 \\
\hline R9 & & & & I can count on my co-workers to give me a hand when I need it. & 0.670 & 0.248 \\
\hline R10 & & & & I cannot speak my mind to my co-workers. & 0.738 & 0.248 \\
\hline G1 & & \multirow{6}{*}{ Growth } & \multirow{6}{*}{$\begin{array}{c}\text { Personal } \\
\text { Development }\end{array}$} & I seldom get the feeling of learning new things from my work. & 0.759 & 0.248 \\
\hline G2 & & & & I have an opportunity to use many of my skills at work. & 0.703 & 0.248 \\
\hline G3 & & & & My job requires that a person use a wide range of abilities. & 0.348 & 0.248 \\
\hline G4 & & & & My job requires making one or more critical decisions every day. & 0.635 & 0.248 \\
\hline G5 & & & & I do not have the opportunity to do challenging things at work. & 0.674 & 0.248 \\
\hline G6 & & & & I do not have the opportunity to do challenging things at work. & 0.611 & 0.248 \\
\hline
\end{tabular}

\begin{tabular}{|c|c|c|c|c|c|}
\hline & Variable & Sub-variable & Question & Pearson & R table \\
\hline P1 & \multirow{13}{*}{$\begin{array}{c}\text { Employee } \\
\text { Performance }\end{array}$} & \multirow{3}{*}{ Work Quality } & The quality of my work is usually high. & 0.777 & 0.248 \\
\hline P2 & & & I deliver higher quality than what can be expected from someone with the type of job that I have. & 0.804 & 0.248 \\
\hline P3 & & & Others in my organisation look at my work as typical high quality work & 0.627 & 0.248 \\
\hline P4 & & \multirow{6}{*}{ Work Effort } & I'm trying to work as hard as I can & 0.889 & 0.248 \\
\hline P5 & & & I'm willing to make a lot of effort to perform my job. & 0.898 & 0.248 \\
\hline P6 & & & I often expend extra effort in carrying out my job. & 0.813 & 0.248 \\
\hline P7 & & & I almost always expend more than an acceptable level of effort & 0.848 & 0.248 \\
\hline P8 & & & I usually don't hesitate to put in extra effort when it is needed. & 0.874 & 0.248 \\
\hline P9 & & & I can finish my work on time. & 0.744 & 0.248 \\
\hline P10 & & \multirow{4}{*}{$\begin{array}{c}\text { Performance } \\
\text { Intentions }\end{array}$} & I often think of improving my job performance. & 0.875 & 0.248 \\
\hline P11 & & & I will actively try to improve my job performance in the future. & 0.894 & 0.248 \\
\hline P12 & & & For the future, I hope to do a lot more at work. & 0.810 & 0.248 \\
\hline P13 & & & I will probably do my best to perform well on the job in the future & 0.880 & 0.248 \\
\hline
\end{tabular}


Proceeding on Management, Education and Social Science (MESS),

$$
\text { Vol. } 1 \text { (1), 22-34 }
$$

The Relationship Between Employee Motivation And Employee Performance in BPR TASPEN

Salsabila Maharani Surya Putri, Nur Arief Rahmatsyah Putranto

\begin{tabular}{|l|c|c|c|c|}
\hline \multicolumn{1}{|c|}{ Variable } & Cronbach Alpha & $\begin{array}{c}\text { Critical } \\
\text { Point }\end{array}$ & $\begin{array}{c}\text { Number of } \\
\text { Items }\end{array}$ & Reliability \\
\hline Existence Needs & 0,879 & 0,6 & 7 & Reliable \\
\hline Relatedness Needs & 0,858 & 06 & 10 & Reliable \\
\hline Growth Needs & 0,683 & 0,6 & 6 & Reliable \\
\hline Employee Performance & 0.961 & 0,6 & 13 & Reliable \\
\hline
\end{tabular}

Fig. 1 Validity and Reliability Test

\subsection{Model 1 Result}

Research results shall pass the classical assumption test to be regarded as a fit model of linier regression. The test then divided into normality, linearity, multicollinearity, and heterodascity test. One-Sample K-S test on Figure 4.2 showed 0.20 significance value thus it is greater than 0.05 hence the data could be categorized as normally distributed.

One-Sample Kolmogorov-Smirnov Test

\begin{tabular}{|c|c|c|}
\hline & & $\begin{array}{l}\text { Unstandardiz } \\
\text { ed Residual }\end{array}$ \\
\hline \multicolumn{2}{|l|}{$\bar{N}$} & 63 \\
\hline \multirow{2}{*}{$\begin{array}{l}\text { Normal } \\
\text { Parameters } \mathrm{a}, \mathrm{b}\end{array}$} & Mean & .0000000 \\
\hline & Std. Deviation & 6.97592526 \\
\hline \multirow{3}{*}{$\begin{array}{l}\text { Most Extreme } \\
\text { Differences }\end{array}$} & Absolute & .098 \\
\hline & Positive & .075 \\
\hline & Negative & -.098 \\
\hline \multicolumn{2}{|l|}{ Test Statistic } & .098 \\
\hline \multicolumn{2}{|c|}{ Asymp. Sig. (2-tailed) } & $.200^{c, d}$ \\
\hline
\end{tabular}

Fig. 2 Normality Test Result

ANOVA test was used to analyse linearity of each needs shown in Figure 4.3. TE (Existence Needs) resulted in F value $1.575<$ F-table 2.27. TR (Relatedness Needs) with F value of $0.946<\mathrm{F}$ table 2.06. TG (Growth Needs) has F value $1.772<$ F-table 2.38. Therefore Existence, Relatedness, and Growth Needs are linear with the dependent variable, employee performance. 
Proceeding on Management, Education and Social Science (MESS),

$$
\text { Vol. } 1 \text { (1), 22-34 }
$$

The Relationship Between Employee Motivation And Employee Performance in BPR TASPEN

Salsabila Maharani Surya Putri, Nur Arief Rahmatsyah Putranto

\begin{tabular}{|c|c|c|c|c|c|c|c|}
\hline & & & Sum of Squares & df & $\begin{array}{l}\text { Mean } \\
\text { Square }\end{array}$ & $\mathrm{F}$ & Sig. \\
\hline & Between & (Combined) & 2629.170 & 20 & 131.458 & 1.869 & .044 \\
\hline & Groups & Linearity & 524.158 & 1 & 524.158 & 7.451 & .009 \\
\hline & & $\begin{array}{l}\text { Deviation from } \\
\text { Linearity }\end{array}$ & 2105.012 & 19 & 110.790 & 1.575 & .109 \\
\hline & \multicolumn{2}{|c|}{ Within Groups } & 2954.767 & 42 & 70.352 & & \\
\hline & \multicolumn{2}{|l|}{ Total } & 5583.937 & 62 & & & \\
\hline
\end{tabular}

\begin{tabular}{|c|c|c|c|c|c|c|c|}
\hline & & & Sum of Squares & df & $\begin{array}{l}\text { Mean } \\
\text { Square }\end{array}$ & $\mathrm{F}$ & Sig. \\
\hline \multirow{5}{*}{$\begin{array}{l}\text { TP } \\
{ }^{*} \\
\text { TG }\end{array}$} & Between & (Combined) & 1606.302 & 12 & 133.858 & 1.683 & .099 \\
\hline & Groups & Linearity & 778.421 & 1 & 778.421 & 9.785 & .003 \\
\hline & & $\begin{array}{l}\text { Deviation } \\
\text { from } \\
\text { Linearity }\end{array}$ & 827.880 & 11 & 75.262 & .946 & 506 \\
\hline & Within Groups & & 3977.635 & 50 & 79.553 & & \\
\hline & Total & & 5583.937 & 62 & & & \\
\hline
\end{tabular}

\begin{tabular}{|ll|r|r|r|r|r|}
\hline & & Sum of Squares & df & \multicolumn{1}{c|}{$\begin{array}{c}\text { Mean } \\
\text { Square }\end{array}$} & \multicolumn{1}{c|}{$\mathrm{F}$} & Sig. \\
\hline $\mathrm{TP}^{*}$ * Between & $\begin{array}{l}\text { (Combined) } \\
\text { TR }\end{array}$ & 3718.694 & 19 & 195.721 & 4.512 & .000 \\
& $\begin{array}{l}\text { Linearity } \\
\text { Deviation } \\
\text { from }\end{array}$ & 2335.334 & 1 & 2335.334 & 53.837 & .000 \\
& $\begin{array}{l}\text { Linearity } \\
\text { Within Groups }\end{array}$ & 1383.359 & 18 & 76.853 & 1.772 & .063 \\
\hline \multicolumn{2}{l|}{ Total } & 1865.243 & 43 & 43.378 & & \\
\hline
\end{tabular}

Fig. 3 Linearity Test Result

Based on Figure 4.4 below, the significance value is above 0.05 . The significance value is higher than 0.05 then it is not having heteroscedascity symptom thus it could be conclude that the data is homocedascity.

\begin{tabular}{|c|c|c|c|c|c|c|}
\hline \multirow{2}{*}{\multicolumn{2}{|c|}{ Model }} & \multicolumn{2}{|c|}{ Unstandardized Coefficients } & \multirow{2}{*}{\begin{tabular}{|c}
$\begin{array}{c}\text { Standardized } \\
\text { Coefficients }\end{array}$ \\
Beta \\
\end{tabular}} & \multirow[b]{2}{*}{$\mathrm{t}$} & \multirow[b]{2}{*}{ Sig. } \\
\hline & & $B$ & Std. Error & & & \\
\hline \multirow[t]{4}{*}{1} & (Constant) & 13.289 & 3.835 & & 3.465 & .001 \\
\hline & $\mathrm{TE}$ & .147 & .120 & .194 & 1.227 & .225 \\
\hline & TR & -.185 & .112 & -.270 & -1.659 & .102 \\
\hline & TG & -.210 & .154 & -.180 & -1.362 & .178 \\
\hline
\end{tabular}

a. Dependent Variable: abs res

Fig. 4 Homocedascity Test Result

The VIF value of Existence, Relatedness, and Growth Needs in Figure 4.5 are in row 1.623, 1.732 , and 1.137 which all of them are below the VIF borders $<10$. The tolerance of Existence, Relatedness, and Growth needs also above 0.1 which indicates that there are no multicollinearity in the data used.

\begin{tabular}{|c|c|c|c|c|c|c|c|c|}
\hline \multirow[b]{2}{*}{ Mod } & & \multicolumn{2}{|c|}{ Unstandardized Coefficients } & \multirow{2}{*}{\begin{tabular}{|c|}
$\begin{array}{c}\text { Standardized } \\
\text { Coefficients }\end{array}$ \\
Beta \\
\end{tabular}} & \multirow[b]{2}{*}{$\mathrm{t}$} & \multirow[b]{2}{*}{ Sig. } & \multicolumn{2}{|c|}{ Collinearity Statistics } \\
\hline & & B & Std. Error & & & & Tolerance & VIF \\
\hline \multirow[t]{4}{*}{1} & (Constant) & 10.866 & 6.231 & & 1.744 & .086 & & \\
\hline & TE & -.257 & .195 & -.161 & -1.318 & .193 & .616 & 1.623 \\
\hline & TR & .987 & .181 & .685 & 5.441 & .000 & .577 & 1.732 \\
\hline & TG & .433 & .251 & .176 & 1.725 & .090 & .879 & 1.137 \\
\hline
\end{tabular}

a. Dependent Variable: TP

Fig. 5 Multicollinearity Test Result 
The rule of thumb of variables which sign a significant value is when it has a value below 0,05 . Based on the Figure 4.6 below, the variables with a significance value above 0,05 thus reject the hypothesis. TE (Existence Needs) and TG (Growth Needs) are rejected while TR (Relatedness Needs) are the only one which accept the hypothesis.

\begin{tabular}{|c|c|c|c|c|c|c|c|c|}
\hline \multirow{2}{*}{\multicolumn{2}{|c|}{ Model }} & \multicolumn{2}{|c|}{ Unstandardized Coefficients } & \multirow{2}{*}{\begin{tabular}{|c|}
$\begin{array}{c}\text { Standardized } \\
\text { Coefficients }\end{array}$ \\
Beta \\
\end{tabular}} & \multirow[b]{2}{*}{$\mathrm{t}$} & \multirow[b]{2}{*}{ Sig. } & \multicolumn{2}{|c|}{ Collinearity Statistics } \\
\hline & & $B$ & Std. Error & & & & Tolerance & VIF \\
\hline \multirow[t]{4}{*}{1} & (Constant) & 10.866 & 6.231 & & 1.744 & .086 & & \\
\hline & TE & -.257 & .195 & -.161 & -1.318 & .193 & .616 & 1.623 \\
\hline & TR & .987 & .181 & .685 & 5.441 & .000 & .577 & 1.732 \\
\hline & TG & .433 & .251 & .176 & 1.725 & .090 & .879 & 1.137 \\
\hline
\end{tabular}

a. Dependent Variable: TP

Fig. 6 T-Test Result

The value of R Square is useful to know how much the contribution of the influence variable motivational needs given simultaneously to the variable employee performance. As shown in Figure 4.7 below, the $\mathrm{R}$ square is $46 \%$ thus variable motivation could explain employee performance as big as $46 \%$ while the rest $54 \%$ influenced by other variables outside the regression equation or the variables which is not become the topic in this research.

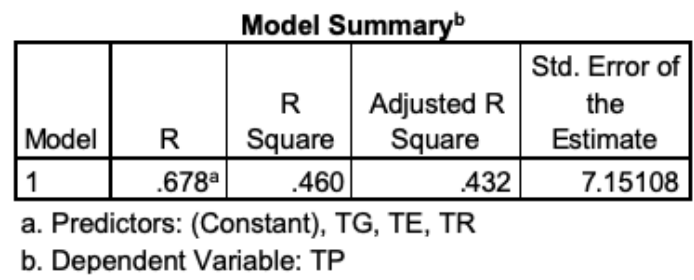

Fig. 7 F- Test Result

How each factor or the variable of motivational needs affect employee performance described in Figure 4.8. Existence Needs will affect Employee Performance 2.86\% (-0.169 squared). Relatedness Needs will affect Employee Performance 33.41\% (0.578 squared). Growth Needs will affect Employee Performance 4.80\% (0.219 squared).

\begin{tabular}{|c|c|c|c|c|c|c|c|c|c|}
\hline \multirow{2}{*}{\multicolumn{2}{|c|}{ Model }} & \multicolumn{2}{|c|}{ Unstandardized Coefficients } & \multirow{2}{*}{$\begin{array}{c}\begin{array}{c}\text { Standardized } \\
\text { Coefficients }\end{array} \\
\text { Beta } \\
\end{array}$} & \multirow[b]{2}{*}{$\mathrm{t}$} & \multirow[b]{2}{*}{ Sig. } & \multicolumn{3}{|c|}{ Correlations } \\
\hline & & B & Std. Error & & & & Zero-order & Partial & Part \\
\hline \multirow[t]{4}{*}{1} & (Constant) & 10.866 & 6.231 & & 1.744 & .086 & & & \\
\hline & TE & -.257 & .195 & -.161 & -1.318 & .193 & .306 & -.169 & -.126 \\
\hline & TR & .987 & .181 & .685 & 5.441 & .000 & .647 & .578 & .521 \\
\hline & TG & .433 & .251 & .176 & 1.725 & .090 & .373 & .219 & .165 \\
\hline
\end{tabular}

Fig. 8 T-Test Partial

\subsection{Model 2 Result}

Kolmogorov-Smirnov test was chosen to predict the value. A normally distribute data will have a significance value above 0.05 . The Figure 4.9 shown the significance value is 0.20 which is greater than 0.05 thus the data used is normally distributed. 


One-Sample Kolmogorov-Smirnov Test
\begin{tabular}{|ll|r|}
\hline & & $\begin{array}{c}\text { Unstandardi } \\
\text { zed } \\
\text { Residual }\end{array}$ \\
\hline $\mathrm{N}$ & Mean & 63 \\
Normal & .0000000 \\
Parameters a,b & Std. & .66148196 \\
Most Extreme & Deviation & Absolute \\
Differences & Positive & .064 \\
& Negative & .063 \\
Test Statistic & & .064 \\
Asvmp. Sig. (2-tailed) & .064 \\
\hline
\end{tabular}

Fig. 9 Normality Test Result

Linearity test in Figure 4.10 aimed to determine whether two variables have a linear relationship or not. Existence Needs resulted in F value $1.266<$ F-table 2.27. Relatedness Needs shown $\mathrm{F}$ value of $1.239<\mathrm{F}$-table 2.06. Growth Needs has $\mathrm{F}$ value is $0.639<\mathrm{F}$-table 2.38, therefore Existence, Relatedness, and Growth Needs are linear with the dependent variable, employee performance.

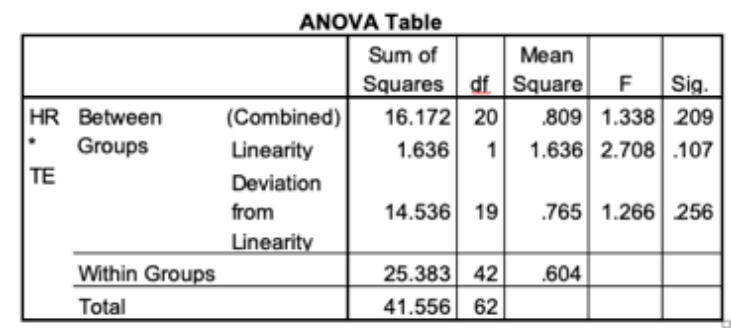

\begin{tabular}{|c|c|c|c|c|c|c|c|}
\hline & & & $\begin{array}{c}\text { Sum of } \\
\text { Squares }\end{array}$ & $d t$ & $\begin{array}{c}\text { Mean } \\
\text { Square }\end{array}$ & $\mathrm{F}$ & Sig. \\
\hline \multirow{5}{*}{$\begin{array}{l}\mathrm{HR} \\
\mathrm{TR} \\
\mathrm{TR}\end{array}$} & \multirow{3}{*}{$\begin{array}{l}\text { Between } \\
\text { Groups }\end{array}$} & (Combined) & 21.970 & 19 & 1.156 & 2.539 & .006 \\
\hline & & Linearity & 11.814 & 1 & 11.814 & 25.937 & .000 \\
\hline & & $\begin{array}{l}\text { Deviation } \\
\text { from } \\
\text { Linearity }\end{array}$ & 10.156 & 18 & .564 & 1.239 & .275 \\
\hline & Within Groups & & 19.586 & 43 & .455 & & \\
\hline & Total & & 41.556 & 62 & & & \\
\hline
\end{tabular}

\begin{tabular}{|c|c|c|c|c|c|c|c|}
\hline & & & $\begin{array}{c}\text { Sum of } \\
\text { Squares }\end{array}$ & $\mathrm{df}$ & \begin{tabular}{c|} 
Mean \\
Square
\end{tabular} & $\mathrm{F}$ & Siq. \\
\hline \multirow{5}{*}{$\begin{array}{l}\text { HR } \\
\cdot \text { TG }\end{array}$} & \multirow{3}{*}{$\begin{array}{l}\text { Between } \\
\text { Groups }\end{array}$} & (Combined) & 9.986 & 12 & .832 & 1.318 & 238 \\
\hline & & Linearity & 5.170 & 1 & 5.170 & 8.188 & .006 \\
\hline & & $\begin{array}{l}\text { Deviation } \\
\text { from } \\
\text { Linearity }\end{array}$ & 4.816 & 11 & .438 & .693 & .738 \\
\hline & Within Groups & & 31.570 & 50 & 631 & & \\
\hline & Total & & 41.556 & 62 & & & \\
\hline
\end{tabular}

Fig. 10 Linearity Test Result

Based on the data shown on Figure 4.11 the significance value of Existence, Relatedness, and Growth Need are above 0.05 . The significance value is higher than 0.05 then it is not having heteroscedascity, thus it could be conclude that the data is homocedascity. 
Proceeding on Management, Education and Social Science (MESS),

$$
\text { Vol. } 1 \text { (1), 22-34 }
$$

The Relationship Between Employee Motivation And Employee Performance in BPR TASPEN

Salsabila Maharani Surya Putri, Nur Arief Rahmatsyah Putranto

\begin{tabular}{|c|c|c|c|c|c|c|}
\hline \multirow{2}{*}{\multicolumn{2}{|c|}{ Model }} & \multicolumn{2}{|c|}{$\begin{array}{c}\text { Unstandardized } \\
\text { Coefficients }\end{array}$} & \multirow{2}{*}{$\begin{array}{c}\text { Standardized } \\
\text { Coefficients }\end{array}$} & \multirow[b]{2}{*}{$\mathrm{t}$} & \multirow[b]{2}{*}{ Sig. } \\
\hline & & B & Std. Error & & & \\
\hline \multirow[t]{4}{*}{1} & (Constant) & .605 & .359 & & 1.684 & .097 \\
\hline & TE & .004 & .011 & .056 & .339 & .736 \\
\hline & TR & -.005 & .010 & -.087 & -.511 & .611 \\
\hline & TG & .001 & .014 & .010 & .069 & .945 \\
\hline
\end{tabular}

a. Dependent Variable: abs_res

Fig. 11 Homocedascity Test Result

According to the Figure 4.12, the VIF value of Existence, Relatedness, and Growth Needs are in row $1.623,1.732$, and 1.137 which all of them are below the VIF borders which is 10 . The tolerance of Existence, Relatedness, and Growth needs also above 0.1 which indicates that there are no multicollinearity in the data used.

\begin{tabular}{|c|c|c|c|c|c|c|c|c|}
\hline \multirow{2}{*}{\multicolumn{2}{|c|}{ Model }} & \multicolumn{2}{|c|}{ Unstandardized Coefficients } & \multirow{2}{*}{\begin{tabular}{|c|}
$\begin{array}{c}\text { Standardized } \\
\text { Coefficients }\end{array}$ \\
Beta \\
\end{tabular}} & \multirow[b]{2}{*}{$\mathrm{t}$} & \multirow[b]{2}{*}{ Sig. } & \multicolumn{2}{|c|}{ Collinearity Statistics } \\
\hline & & $B$ & Std. Error & & & & Tolerance & VIF \\
\hline \multirow[t]{4}{*}{1} & (Constant) & .519 & .591 & & .878 & .383 & & \\
\hline & $\mathrm{TE}$ & -.031 & .018 & -.223 & -1.664 & .102 & .616 & 1.623 \\
\hline & TR & .075 & .017 & .602 & 4.351 & .000 & .577 & 1.732 \\
\hline & TG & .042 & .024 & .199 & 1.777 & .081 & .879 & 1.137 \\
\hline
\end{tabular}

a. Dependent Variable: HR

Fig. 12 Multicollinearity Test Result

The rule of thumb of variables which sign a significant value is when it has a value below 0,05 . The variables with a significance value above 0,05 will reject the hypothesis. Hence TE (Existence Needs) and TG (Growth Needs) are rejected while TR (Relatedness Needs) is the only one which accept the hypothesis because it has 0.00 showed in Figure 4.13

\begin{tabular}{|c|c|c|c|c|c|c|c|c|}
\hline \multirow{2}{*}{\multicolumn{2}{|c|}{ Model }} & \multicolumn{2}{|c|}{ Unstandardized Coefficients } & \multirow{2}{*}{$\begin{array}{c}\begin{array}{c}\text { Standardized } \\
\text { Coefficients }\end{array} \\
\text { Beta }\end{array}$} & \multirow[b]{2}{*}{$t$} & \multirow[b]{2}{*}{ Sig. } & \multicolumn{2}{|c|}{ Collinearity Statistics } \\
\hline & & B & Std. Error & & & & Tolerance & VIF \\
\hline \multirow[t]{4}{*}{1} & (Constant) & .519 & .591 & & .878 & .383 & & \\
\hline & TE & -.031 & .018 & -.223 & -1.664 & .102 & .616 & 1.623 \\
\hline & TR & .075 & .017 & .602 & 4.351 & .000 & .577 & 1.732 \\
\hline & TG & .042 & .024 & .199 & 1.777 & .081 & .879 & 1.137 \\
\hline
\end{tabular}

a. Dependent Variable: HR

Fig. 13 T-Test Result

The value of R Square is useful to know how much the contribution of the influence variable motivational needs given simultaneously to the variable employee performance. As shown in Figure 4.14 the $\mathrm{R}$ square is 0.347 or $34.7 \%$ thus variable motivation could explain employee performance as big as $34.7 \%$ while the $66.3 \%$ influenced by other variables outside the regression equation or the variables which is not examined.

\begin{tabular}{|l|l|c|c|c|}
\hline Model & $\mathrm{R}$ & $\begin{array}{c}\mathrm{R} \\
\text { Square }\end{array}$ & $\begin{array}{c}\text { Adjusted R } \\
\text { Square }\end{array}$ & $\begin{array}{c}\text { Std. Error of } \\
\text { the } \\
\text { Estimate }\end{array}$ \\
\hline 1 & $.589^{\mathrm{a}}$ & .347 & .314 & .678 \\
\hline
\end{tabular}

a. Predictors: (Constant), TG, TE, TR

Fig. 14 F- Test Result 
How each factor or the variable of motivational needs affect employee performance described in Figure 4.15 Existence Needs will affect Employee Performance 4.5\% (-0.212 squared). Relatedness Needs will affect Employee Performance 24.30\% (0.493 squared). Growth Needs will affect Employee Performance 5.06\% (0.225 squared).

\begin{tabular}{|c|c|c|c|c|c|c|c|c|c|}
\hline \multirow{2}{*}{\multicolumn{2}{|c|}{ Model }} & \multicolumn{2}{|c|}{ Unstandardized Coefficients } & \multirow{2}{*}{\begin{tabular}{|c|}
$\begin{array}{c}\text { Standardized } \\
\text { Coefficients }\end{array}$ \\
Beta \\
\end{tabular}} & \multirow[b]{2}{*}{$\mathrm{t}$} & \multirow[b]{2}{*}{ Sig. } & \multicolumn{3}{|c|}{ Correlations } \\
\hline & & B & Std. Error & & & & Zero-order & Partial & Part \\
\hline \multirow[t]{4}{*}{1} & (Constant) & .519 & .591 & & .878 & .383 & & & \\
\hline & TE & -.031 & .018 & -.223 & -1.664 & .102 & .198 & -.212 & -.175 \\
\hline & TR & .075 & .017 & .602 & 4.351 & .000 & .533 & .493 & .458 \\
\hline & TG & .042 & .024 & .199 & 1.777 & .081 & .353 & .225 & .187 \\
\hline
\end{tabular}

a. Dependent Variable: HR

Fig. 15 T-Test Partial

\subsection{Significance Between Motivational Needs and Employee Performance}

Based on the explanation from Model 1 and Model 2 we can conclude that Existence Needs which consist of good pay and fringe benefits are positively affect employee performance. It has the smallest impact towards employee performance. BPR DP Taspen apply pay for performance as their compensation system. As with other HRM strategies, the performance-related pay for employees could be ineffective due to its positive association with work intensification. Work intensification correlated with the potential to distract from its positive effect on job satisfaction, employee engagement and hence pointing to employee performance (Ogbonnaya et al., 2017). Rather than motivating employees, incentive-based pay structures end up having low effects. Ogbonnaya et al. (2017) revealed that Employees who receive a pay for performance work harder, but they also experience greater stress and less satisfaction in the workplace. By connecting job performance to financial benefits, employers are sending signals to workers about their plan to pay for more work, employees receive those signals on their own and feel compelled to work harder for more pay. Such system of pay ensures that only the most successful workers survive.

Relatedness needs that composed of respect from superiors and peers gives a significant effect towards employee performance by contribute the highest percentage towards employee performance. The relatedness needs refer to man's desire to maintain important interpersonal relationships which are man's social, acceptance, belongingness and status desires. Align with Arnolds \& Boshoff (2002) in their research, the number one ranked motivation factor is recognition from manager and others. It is necessary to prioritize the use employees closeness to encourage them to work. It also relates to the employer's market which is retired civil servants whose to get their market, the employees needs to communicate properly with older people.

Growth Needs which explains personal development emphasize on learning about new things at work, optimal skills use, decision-making participation, and work challenge opportunities participates in the variable with almost gives significant affect to employee performance. This might occur because the satisfaction of this needs may vary for each employees. Further, ERG theory recognizes that the individual can return to a level that appears easier to achieve if a higher level of needs remains unfulfilled. The employees do not achieve growth opportunities, so they may return to relatedness needs regarding the fact that the growth needs are unattainable.

\section{CONCLUSION AND FURTHER RESEARCH}

Using Multi Linear Regression, researcher have identified and analysed both independent and dependent variables mentioned. Based on the analysis of model 1 and model 2, the relatedness needs seems to be the dominant factor of motivational needs that have a significant impact on employee performance. Meanwhile, the needs for existence and growth have no significant effect on employee engagement in BPR TASPEN. Therefore, it can be concluded that if employers focus on the 
relatedness needs, or use relatedness as a base to collaborate with other needs, the motivation of employees to perform best may increase. Factors such as recognition and respect appear to be more powerful motivators of behavior in the workplace hence the work environment could play a key role in conducting future research. This is also supported by the fact that $34.7 \%-46 \%$ of employee motivation can be explained by motivation. Hence the future research expectantly could add other variables to describe the rest of $65.3 \%-54 \%$. The research limitation is the result only applicable to the staff of BPR TASPEN. The management of the company, such as directors, commissioners, and shareholders, are not counted as employees.

\section{REFERENCES}

Arnolds, C. A., \& Boshoff, C. (2002). Compensation, esteem valence and job performance: An empirical assessment of Alderfer's ERG theory. International Journal of Human Resource Management, 13(4), 697-719. https://doi.org/10.1080/09585190210125868

Alderfer, C. P. (1969). An empirical test of a new theory of human needs. Organizational Behavior and Human Performance, 4(2), 142-175. https://doi.org/10.1016/0030-5073(69)90004-X

Alexakis, C., Izzeldin, M., Johnes, J., \& Pappas, V. (2019). Performance and productivity in Islamic and conventional banks: Evidence from the global financial crisis. Economic Modelling, 79, 1-14. doi:10.1016/j.econmod.2018.09.030

Beltrán-Martín, I., \& Bou-Llusar, J. C. (2018). Examining the intermediate role of employee abilities, motivation and opportunities to participate in the relationship between HR bundles and employee performance. BRQ Business Research Quarterly, 21(2), 99-110. https://doi.org/10.1016/j.brq.2018.02.001

Ghozali, Imam. 2001. Aplikasi Analisis Multivariate Dengan Program SPSS. Semarang: Badan Peneliti Universitas Diponegoro.

Caulton, J. (2012). The development and use of the theory of erg: A literature review. Emerging Leadership Journeys, 5(1), 2-8.

Chiang, C. F., \& (Shawn) Jang, S. C. (2008). An expectancy theory model for hotel employee motivation. International Journal of Hospitality Management, 27(2), 313-322. https://doi.org/10.1016/j.ijhm.2007.07.017

Chhugani, K. (2018, March 19). The importance of Human Resources to an Organization. Retrieved July 06, 2020, from https://www.easyhrworld.com/the-importance-of-human-resources-to-anorganization/

Deci, E. L., Olafsen, A. H., \& Ryan, R. M. (2017). Self-Determination Theory in Work Organizations: The State of a Science. Annual Review of Organizational Psychology and Organizational Behavior, 4(1), 19-43. https://doi.org/10.1146/annurev-orgpsych-032516-113108

Dugovicova, J. (2019). Impact of Employee Motivation on Employee Retention Rates. 6(23), 159-167.

Ho, C. and Zhu, D. (2004), "Performance measurement of Taiwan's commercial banks", International Journal of Productivity and Performance Management, Vol. 53 No. 5, pp. 425-434. https://doi.org/10.1108/17410400410545897

Iskandar, S. (2013). Bank dan Lembaga Keuangan Lainnya. Jakarta: In Media.

Jiang, K., Lepak, D. P., Hu, J., \& Baer, J. C. (2012). How does human resource management influence organizational outcomes? A meta-analytic investigation of mediating mechanisms. Academy of Management Journal, 55(6), 1264-1294. https://doi.org/10.5465/amj.2011.0088

Jerome, N. (2013). Application of the Maslow's hierarchy of need theory; impacts and implications on organizational culture, human resource and employee's performance. International Journal of Business and Management Invention ISSN (Online, 2(3), 23198028.

Kasmir. 2012. Bank dan Lembaga Kuangan Lainnya. Jakarta: PT. Raja Grafindo Persada. 
Nnenna E. Ukandu. (2011). Strategies to improve the level of employee motivation in the fast food outlets in Cape Town, South Africa. African Journal of Business Management, 5(28), 11521-11531. https://doi.org/10.5897/ajbm11.1476

Ogbonnaya, C., Daniels, K., \& Nielsen, K. (2017). Does contingent pay encourage positive employee attitudes and intensify work? Human Resource Management Journal, 27(1), 94-112. https://doi.org/10.1111/1748-8583.12130

Pradhan, R. K., \& Jena, L. K. (2017). Employee Performance at Workplace: Conceptual Model and Empirical Validation. Business Perspectives and Research, 5(1), 69-85. https://doi.org/10.1177/2278533716671630

Rhee, H. (2019). Comparison of Process Theories to Content Theories in Motivating Workforces. International Journal of Human Resource Studies, 9(4), 267-274. https://doi.org/10.5296/ijhrs.v9i4.15620

Sato, M., Maufi, D., Mwingira, U. J., Leshabari, M. T., Ohnishi, M., \& Honda, S. (2017). Correction: Measuring three aspects of motivation among health workers at primary level health facilities in rural Tanzania (PLoS ONE (2017) 12:5 (e0176973) DOI: 10.1371/journal.pone.0176973). PLoS ONE, 12(9), 1-17. https://doi.org/10.1371/journal.pone.0184599

Sugiyono. 2013. Metode Penelitian Pendidikan Pendekatan Kuantitatif, Kualitatif, dan R\&D. Bandung: Alfabeta

Staroňová, K. (2017). Performance Appraisal in the Eu Member States and the European Commission.

Taghipour, A., \& Dejban, R. (2013). Job Performance: Mediate Mechanism of Work Motivation. Procedia - Social and Behavioral Sciences, 84, 1601-1605. https://doi.org/10.1016/j.sbspro.2013.06.796

Webb, E., Perry, M., \& Fennelly, L. J. (2015). Employee Motivation Theory and Application. In Security Supervision and Management: Theory and Practice of Asset Protection: Fourth Edition (Fourth Edi). https://doi.org/10.1016/B978-0-12-800113-4.00018-3

Wiley, C. (1997). What motivates employees according to over 40 years of motivation surveys. International Journal of Manpower, 18(3), 263-280. https://doi.org/10.1108/01437729710169373

Zámečník, R. (2014). The Measurement of Employee Motivation by Using Multi-factor Statistical Analysis. Procedia - Social and Behavioral Sciences, 109(1998), 851-857. https://doi.org/10.1016/j.sbspro.2013.12.553 